\title{
Effect of phytase dose on productive performance and bone status of layers fed with graded levels of digestible lysine
}

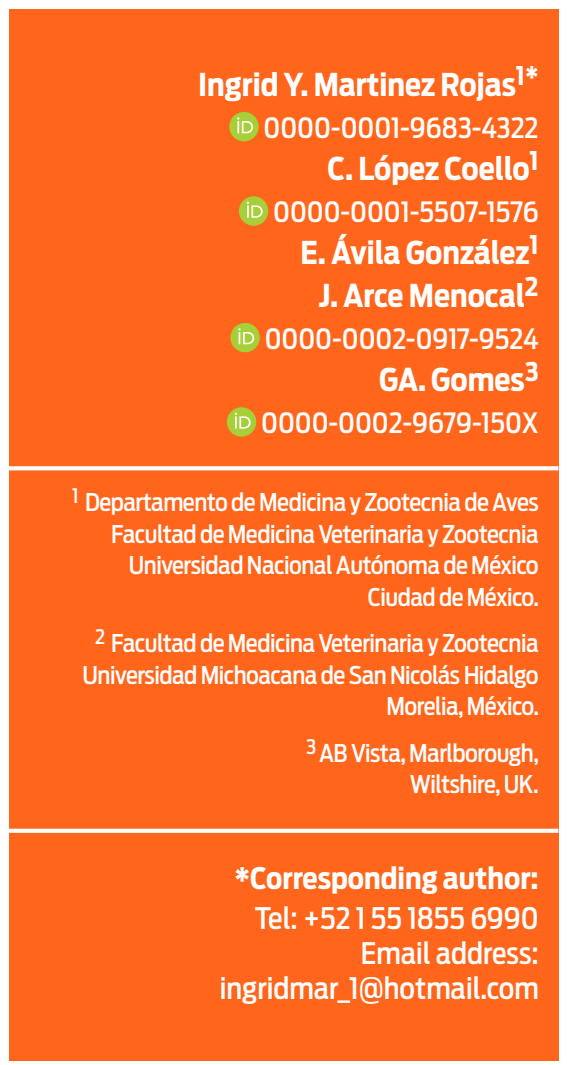

Received: 2017-12-21

Accepted: $2018-04-25$

Published: 2018-08-07

Additional information and declarations can be found on page 16

@) Copyright 2018 Ingrid Y. Martinez Rojas et al.

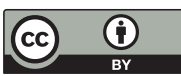

Distributed under Creative Commons CC-BY 4.0

\begin{abstract}
Exogenous phytase could influence dietary protein availability by variation in using dose. The objective of the present study was to determine if incremental dosing of an evolved E.coli 6-phytase would lead to improvements in lysine availability through evaluating performance and bone status in Bovans White layers. A total of 182 layers were placed in individual cages and distributed to 13 treatments: a $3 \times 4$ factorial arrangement with three levels of digestible lysine (dLys - 0.67, 0.77, and $0.87 \%$ ) and four doses of phytase $(0,300,1200$, and $4800 \mathrm{FTU} / \mathrm{kg}$ ) in $0.12 \%$ available P (avP) diets. Additionally, one phytase-free control treatment was included with $0.25 \%$ avP and $0.87 \%$ dLys. Productive parameters were recorded for 25 weeks, from 39 week-old. At the end, abdominal fat deposition and the tibia were sampled; in bone was determined breaking strength and bone ash. Layers fed $1200 \mathrm{FTU} / \mathrm{kg}$ phytase increased egg production percentage $\left(F_{3,169}=2.01, P=0.111\right)$, abdominal fat deposition $\left(F_{3,169}=2.52\right.$, $P=0.059)$, bone breaking strength $\left(F_{3,169}=4.29, P=0.006\right)$ and bone ash weight $\left(F_{3,169}=3.62, p=0.014\right)$ compared with non-phytase inclusion. Furthermore, $1200 \mathrm{FTU} / \mathrm{kg}$ phytase decreased incidence of broken eggs and soft-shell eggs $\left(F_{3,169}=2.9, p=0.036\right)$. Phytase and dLys levels influenced egg mass and bone ash concentration $\left(F_{12,169}=1.86, p=0.043\right)$. FCR and body weight loss was reduced with phytase inclusion (respectively: $F_{12,169}=2.43, p=0.006$, and $F_{12,169}=2.24, p=0.012$ ). Phytase-free control diet increased egg weight $\left(F_{12,169}=3.70, p<0.001\right)$, but gave greater BW loss $\left(F_{12,169}=17.79, p<0.001\right)$, less abdominal fat content $\left(F_{12,169}=5.85, p<0.001\right)$, and no effect on other variables $(p>0.07)$. In conclusion, $1200 \mathrm{FTU} / \mathrm{kg}$ of phytase improved productive performance and preserved body weight and bone status, without equivalence of phytase inclusion for dLys level, even with higher doses.
\end{abstract}

Keywords: bone parameters, digestible lysine, laying hens, phytase dose, productive performance.

\section{Cite this as:}

Martínez Rojas IY, López Coello C, Ávila González E, Arce Menocal J, Gomes CA. Effect of phytase dose on productive performance and bone status of layers fed with graded levels of digestible lysine. Veterinaria México OA. 2018;5(3). doi: 10.22201/ fmvz.24486760e.2018.3.564 


\section{Introduction}

Phytic acid represents 60 to $80 \%$ of phosphorus (P) stored in vegetables, ${ }^{1}$ and is essential for the germination process. Phytic acid plays a critical anti-oxidant role in dormant seeds, ${ }^{2}$ but in diets for monogastric animals it is considered as an antinutrient due to its chelating capacity with minerals, carbohydrates, proteins ${ }^{3}$ and amino acids. ${ }^{4}$ The fact that poultry species have limited ability to hydrolysis phytic acid $^{5}$ and release $P$ from its structure, addition of exogenous microbial phytase in diets is a common practice nowadays. This strategy allows the reduction of inorganic $\mathrm{P}$ supplementation in the diet, decreasing $\mathrm{P}$ excretion and therefore to mitigating environmental pollution. ${ }^{6}$ This phosphoric effect of phytase is embraced worldwide in poultry and swine production; however, the consequences of phytase in the release of other nutrients, known as the extra-phosphoric effect, ${ }^{7}$ has been under research in recent years. ${ }^{8}$

Phytic acid can negatively affect the solubility and digestion of proteins, likely through two paths of action. One mechanism is related to the chelation of protein by phytic acid and depends on isoelectric point of the protein and the $\mathrm{pH}$ of the digesta. In an acidic $\mathrm{pH}$, phytic acid can directly chelate positive charges in the $\alpha-\mathrm{NH}_{2}$ group or to some basic amino acids, such as arginine, histidine, and lysine, forming binary complexes. In a basic $\mathrm{pH}$, negative charges on the carboxyl group of all amino acids bind with divalent cations, mainly minerals, which are chelated by phytic acid, ending up in the formation of tertiary complexes. ${ }^{9}$ The other mechanism is based on the capacity of phosphate groups to act as a kosmotropic substance. ${ }^{10}$ In this case, phosphate groups are able to establish hydrogen bonds with water surrounding proteins, changing protein structure to a rigid status. Thus, protein solubility and digestion is reduced in the digestive tract. Bye et al. ${ }^{11}$ concluded that sodium phytate decreased solubility and stability of lysozyme in vitro, acting as a kosmotropic molecule at concentrations higher than $5 \mathrm{mM}$, whereas at concentrations lower than $5 \mathrm{mM}$, direct binding of sodium phytate was responsible for the destabilization of the protein.

Lysine is often considered as the reference amino acid in the ideal amino acid profile concept applied to animal feed formulation, ${ }^{12}$ despite methionine is the first limiting amino acid in poultry. Lysine was chosen taking into account that laboratory analysis is easier, lysine's only role is in body accretion and egg deposition, and also because it is not turned to any other amino acid. ${ }^{10}$ Formulating diets with the ideal profile concept sets lysine requirements first, expecting that the remaining amino acid requirements can be adjusted in a fixed manner relative to lysine. ${ }^{13}$ In the case of laying hens, requirement for digestible lysine (dLys) depends on factors such as bird age, productive period, and genetic line, which could affect the response in egg mass and body weight. ${ }^{14}$

Taking into consideration the effect that phytic acid has on protein solubility, it is possible that phytase can affect dietary amino acid requirements of laying hens, although the response could be influenced by enzyme dose. It is expected that higher doses of phytase could improve utilization of protein content in the diet in comparison to the standard $300 \mathrm{FTU} / \mathrm{kg}$ dose, ${ }^{15}$ related to greater phytic acid hydrolysis in the digestive tract. ${ }^{16}$ Implementation of these high doses, known as superdosing, in broiler has led to addition of $1500 \mathrm{FTU} / \mathrm{kg}$ in order to obtain hydrolysis of more than $85 \%$ of the phytic acid present in the diet, ${ }^{17}$ resulting in better animal performance. ${ }^{7}$ In the case of standard doses, Selle et al. ${ }^{18}$ indicated 
that inclusion of $766 \mathrm{FTU} / \mathrm{kg}$ would result in $42 \%$ phytic acid degradation, and that the $\mathrm{P}$ equivalency for $500 \mathrm{FTU} / \mathrm{kg}$ is $0.12 \%$ available $\mathrm{P}$ (avP) in the case of broilers and pigs, which establishes hydrolyzed capacity and $\mathrm{P}$ supply for standard doses.

In laying hens, most of published phytase studies have included doses of 300 to $400 \mathrm{FTU} / \mathrm{kg}^{19-21}$ and there is lack of information about use of higher doses. No differences were observed by Mellef et al. 22 when evaluating 400, 800, and $1200 \mathrm{FTU} / \mathrm{kg}$ in 30 week-old Shaver 2000 layers. Similarly, Silva et al. did not observe any differences with 300, 600 or $1200 \mathrm{FTU} / \mathrm{kg}$ in 44 week-old Lohmann Brown layers. With the same strain, Agbede et al. ${ }^{23}$ tested 0 and $1000 \mathrm{FTU} / \mathrm{kg}$ between $18^{\text {th }}$ and $22^{\text {th }}$ week of age, with no change in the response to phytase addition. These studies suggest that, although diverse experimental conditions were employed, higher doses of phytase did not exhibit positive results in laying hens.

Studies that evaluate the extra-phosphoric effect of phytase are not currently available in laying hens. Additionally, interactive effects of phytase doses and dLys levels in diet have only reported in broilers. ${ }^{24}$ In the current study, it was hypothesized that incremental doses of a 6-phytase derived from E.coli would increase dietary lysine availability and consequently would enhance production in Bovans White hens from 40 to 63 weeks of age. Therefore, the aim of the present study was to evaluate the effect of four doses of phytase $(0,300,1200$, and 4800 FTU/ $\mathrm{kg}$ ) and three levels of dLys (0.67, 0.77 , and $0.87 \%)$ on production and bone parameters of laying hens fed a corn and soybean meal based diet deficient in avP $(0.12 \%)$. Enzyme effect was also compared with inorganic $P$ addition by increasing avP level to $0.25 \%$ in a positive control.

\section{Materials and methods}

\section{Laying hens}

A total of 182, 39 week-old Bovans White hens were individually placed in $40 \times 47 \mathrm{~cm}$ cages, equivalent to $1880 \mathrm{~cm}^{2}$ of available surface area per hen, with individual space of $38 \mathrm{~cm}$ in a channel feeder. At the beginning of the test, hens were selected by BW, with a range of $1653 \pm 135 \mathrm{~g}$ (equivalent to one standard deviation). Laying rate was evaluated for the first week, and hens that did not lay regularly were discarded. Hens had access to water ad libitum and to a maximum feed intake of $105 \mathrm{~g} / \mathrm{hen} / \mathrm{d}$ with diet in mash presentation. Facilities were at environmental temperature and hens had a lighting program of 16L:8D. All hen handling procedures were approved by the Institutional Subcommittee for the Care and Use of Experimental Animals (SICUAE) of the Facultad de Medicina Veterinaria y Zootecnia of the Universidad Nacional Autónoma de México.

\section{Diets and experimental design}

Four doses of an exogenous phytase were included in $0.12 \%$ avP diets $(0,300$, 1200 , and $4800 \mathrm{FTU} / \mathrm{kg}$ ) with three levels of dLys (0.67, 0.77, and $0.87 \%$, in a $4 \times 3$ factorial manner. An additional phytase-free diet with $0.25 \%$ avP and $0.87 \%$ dLys was included as a control diet, for a total of 13 treatments. Hens with regular egg laying and adequate BW were randomly assigned into treatments, each with 14 replicates of one hen. 
Table 1. Composition of basal experimental diet and analyzed nutrient content

\begin{tabular}{|c|c|}
\hline Ingredient & Kilograms/tonne \\
\hline Yellow corn (8 \% CP) & 690 \\
\hline Soybean meal (48 \% CP) & 200 \\
\hline Calcium carbonate & 94.3 \\
\hline Salt $(\mathrm{NaCl})$ & 4 \\
\hline Cellulose & 3 \\
\hline Vitamins and minerals $^{1}$ & 2.4 \\
\hline DL-methionine 84 \% & 1.6 \\
\hline Ortophosphate 18:21 & 1.3 \\
\hline Yellow pigment 15 g/kg (Tagetes erecta) & 1 \\
\hline Red pigment $5 \mathrm{~g} / \mathrm{kg}$ (Capsicum annuum) & 0.8 \\
\hline Choline chloride $60 \%$ & 0.8 \\
\hline BMD $-100^{2}$ & 0.5 \\
\hline Cyromazine $1 \%$ & 0.5 \\
\hline Antioxidant ${ }^{2}$ & 0.2 \\
\hline L-Lysine $76.4 \%$ & 0 \\
\hline Escherichia coli phytase & 0 \\
\hline \multicolumn{2}{|c|}{ Analyzed nutrient content } \\
\hline Crude protein $(\%)^{\dagger}$ & 15.1 \\
\hline Metabolizable energy (Mcal/kg) ${ }^{\dagger}$ & 2.80 \\
\hline Digestible methionine and cysteine $(\%)^{\dagger \dagger}$ & 0.65 \\
\hline Digestible methionine $(\%)^{\dagger \dagger}$ & 0.38 \\
\hline Digestible lysine $(\%)^{\dagger}$ & 0.67 \\
\hline Digestible threonine $(\%)^{\dagger \dagger}$ & 0.61 \\
\hline Total calcium $(\%)^{\dagger}$ & 3.5 \\
\hline Total phosphorus (\%) ${ }^{\dagger}$ & 0.34 \\
\hline Available phosphorus (\%) ${ }^{\dagger}$ & 0.12 \\
\hline
\end{tabular}

† Value analyzed; ttValue calculated.

${ }^{1}$ Vitamin premix provided Vitamin A 10000000 Ul; Vitamin D3 2500000 Ul; Vitamin E 6000 Ul; Vitamin K 2.5 g; Thymine 1.6 g; Riboflavin 5 g; Cyanocobalamin 0.10 g, Folic acid 0.50 g; Pyridoxine 1.5 g; Calcium pantothenate 10 g; Niacina 30 g; Choline chloride 60 \% 200 g, Iron 80 g; Manganese 60 g; Copper 10 g; lodine 0.3 g; Zinc 50 g; Selenium 0.30 g; Antioxidant 125 g; Vehicle cbp 1000 000g per kg diet.

2 BHA (Butyl hydroxy anisole) $1.2 \%$, BHT (Butyl hidroxy toluene) $9 \%$, Ethoxiquine $4.8 \%$, Chelating agents $10 \%$.

A corn-soybean meal based diet was prepared and split into 13 equal parts, representing the treatment diets; for each, micro-ingredients and enzyme were added to get the nutritional content according to experimental design (Table 1). The nutritional content of the basal diet was established following the NRC recommendations for white line hens, ${ }^{25}$ except for dLys and avP, which were defined according to the intrinsic goals of the study. All diets contained $15 \%$ crude protein, $2.8 \mathrm{Mcal} / \mathrm{kg}$, and $3.5 \%$ total $\mathrm{Ca}$, and were formulated based on digestible amino acids, keeping constant the content of digestible methionine (0.38\%), digestible cysteine-methionine $(0.65 \%)$, and digestible threonine $(0.61 \%)$. Cellulose (World Minerals, Lompoc, $\mathrm{CA}$ ) was added as an inert material, including L-Lys $\mathrm{HCl}$ and phytase at the expense of it, providing the target levels for the experimental diets. 
During the experiment, a phytase from Escherichia coli expressed in Trichoderma reesei was used (Quantum Blue, EC 3.1.3.26, AB Vista, Marlborough, UK). FTU was defined as the amount of enzyme required to release one mol of inorganic $\mathrm{P} /$ min from $0.15 \mathrm{M} / \mathrm{dL}$ of sodium phytate at a temperature of $37^{\circ} \mathrm{C}$ in $\mathrm{pH} 5.5$.

\section{Productive parameters}

Layer production was recorded for 25 weeks. The laying rate, egg weight, and egg classification (broken, dirty and soft-shell) were recorded daily for each replicate. No mortalities were observed during the experimental period. Cumulative feed consumption was measured weekly and body weight at the beginning and end of the experiment.

\section{Egg quality testing}

Every four weeks, one egg per replica was used to determine Haugh units and yolk pigmentation using a TSS QCD computer system (Technical Services and Supplies, Dunnington, York, UK). In the same egg, shell thickness without internal membranes was measured with a digital micrometer (Mitutoyo Corp., Kawasaki, Japan).

\section{Bone parameters and abdominal fat deposition}

After the experimental period, 12 hens per treatment were euthanized by an intravenous injection of EUTAFIN ${ }^{\circledR}$ (390 mg sodium pentobarbital, $50 \mathrm{mg}$ phenytoin sodium and $1 \mathrm{~mL}$ excipients; UNAM, Mexico City) at a dose of $1 \mathrm{~mL} / 5 \mathrm{~kg}$ of BW into the radial vein. Both tibias from all hens were sampled; the right tibia were used to determine bone breaking strength using MV-1 10 Imada equipment (Imada Inc., Northbrook, IL), ensuring a fixed distance of $3.6 \mathrm{~cm}$ between the two supporting columns. The left tibia were cleaned of muscle remains, joints, tendons and ligaments, degreased with $25 \%$ ethylic ether in a Soxhlet extractor for four hours, dried at $50^{\circ} \mathrm{C}$ for 48 hours, and weighed. The dehydrated bones were incinerated at $500{ }^{\circ} \mathrm{C}$ for 17 hours in order to determine ash content. Additionally, abdominal fat content was weighed for each hen, and expressed as a percent of final BW.

\section{Laboratory analysis in feed}

Protein, ME, P, and Ca content were analyzed in the basal diet, following AOAC techniques (2006). Exogenous phytase activity in diet samples was analyzed by the Enzyme Services and Consultancy (ESC, Ystrad Mynach, UK) according to a modified method as proposed by Engelen et al. ${ }^{19}$. Lysine concentration was quantified in treatment diets according to AOAC. ${ }^{26}$

\section{Statistical analysis}

Treatments with $0.12 \%$ of avP were analyzed as a crossed arrangement structure nested in avP content of the diet, which was also added as source of variation in the ANOVA. Means of treatment interactions and main effects were separated using a Tukey's or least significant difference test. Additionally, regression analyses 
were applied, taking phytase and dLys as quantitative variables. $\mathrm{P}<0.07$ indicated statistically signification using JMP software $12{ }^{\circledR}($ SAS, NC, USA).

\section{Results and discussion}

Analysed enzyme activity in all treatments was above the expected, but they were present in accordance with target dose, which confirmed that the enzyme was present in diets, in gradually increasing levels (Table 2). Diets without addition of exogenous enzyme were not analyzed because the assay technique is specific for the exogenous microbial phytase. There are several factors that can affect the exogenous phytase quantification in feeds, including sampling conditions in the farm or laboratory processing when the enzyme activity is determined. ${ }^{27}$ Despite assay, values being higher than expected, they confirmed that the interpretation of the results in this study could be based on the initially proposed doses. In the case of dLys dietary, contents were similar to expected levels (see footnote in Table 3).

A positive effect on egg production was seen when phytase was included in the diet, although the extent of the response was linked to enzyme dose employed. Layers fed $1200 \mathrm{FTU} / \mathrm{kg}$ phytase had higher egg production percentage than those fed no phytase in $0.12 \%$ avP diets, $F_{3,169}=2.01, p=0.03$. Furthermore, layers fed 300 and $4800 \mathrm{FTU} / \mathrm{kg}$ phytase in $0.12 \%$ avP diets or with $0.25 \%$ avP in the phytase-free diet did not show statistical differences from those fed $1200 \mathrm{FTU} / \mathrm{kg}$ phytase. The response in percent egg production to incremental phytase dose was quadratic, showing evidence of maximum production at $1200 \mathrm{FTU} / \mathrm{kg} \mathrm{F}_{2,179}=6.39, \mathrm{p}=0.01$ (Table 3). Mellef et al. ${ }^{22}$ reported that inclu-

Table 2. Expected and analyzed ${ }^{1}$ phytase activity in feed samples

\begin{tabular}{|c|c|c|c|}
\hline $\begin{array}{l}\text { Expected } \\
\left(\mathrm{FTU}^{2} / \mathrm{kg}\right)\end{array}$ & Digestible lysine ( $\%$ ) & $\begin{array}{l}\text { Analyzed } \\
\text { (FTU/kg) }\end{array}$ & Recovery (\%) \\
\hline 300 & \multirow{3}{*}{0.67} & 485 & 162 \\
\hline 1200 & & 1340 & 112 \\
\hline 4800 & & 5345 & 111 \\
\hline 300 & \multirow{3}{*}{0.77} & 402 & 134 \\
\hline 1200 & & 1400 & 117 \\
\hline 4800 & & 5498 & 115 \\
\hline 300 & \multirow{3}{*}{0.87} & 390 & 130 \\
\hline 1200 & & 1600 & 133 \\
\hline 4800 & & 5780 & 120 \\
\hline
\end{tabular}

${ }^{1}$ Feed samples were analyzed by Enzyme Services and Consultancy Ltd.- Ystrad Mynach, UK according to manufacturer's recommendations.

${ }^{2}$ One FTU is defined as the amount of enzyme required to release $1 \mu$ mol of inorganic $\mathrm{P}$ per minute from $0.15 \mathrm{M}$ of sodium phytate at $37^{\circ} \mathrm{C}$ and pH 5.5. 
Table 3. Effect of phytase and digestible lysine on production parameters and abdominal fat deposition

in 40-65 week-old White Bovans laying hens

\begin{tabular}{|c|c|c|c|c|c|c|c|c|c|c|c|}
\hline \multirow{2}{*}{$\operatorname{AvP}(\%)$} & \multirow{2}{*}{$\begin{array}{l}\text { Phytase (FTU/ } \\
\text { kg) }\end{array}$} & \multirow{2}{*}{$\begin{array}{l}\text { Dig.lysine } \\
(\%)\end{array}$} & \multirow{2}{*}{ Egg production (\%) } & \multirow{2}{*}{$\begin{array}{l}\text { Egg weight } \\
\text { (g) }\end{array}$} & \multirow{2}{*}{$\begin{array}{l}\text { Feed consumption } \\
\text { (g/hen/day) }\end{array}$} & \multirow{2}{*}{ Egg mass (g) } & \multirow{2}{*}{ FCR $\quad(g / g)$} & \multicolumn{3}{|c|}{ Body weight (g) } & \multirow{2}{*}{$\begin{array}{l}\text { Abdominal fat } \\
\text { deposition (\%) }\end{array}$} \\
\hline & & & & & & & & Initial (g) & Final (g) & Loss ( $\%)$ & \\
\hline \multirow{12}{*}{0.12} & 0 & \multirow{4}{*}{$0.67^{1}$} & 85.9 & 58.7 & 102.5 & $50.3^{b}$ & 2.04 & 1620 & 1531 & 5.2 & 1.94 \\
\hline & 300 & & 87.1 & 62 & 103.2 & $53.8^{\mathrm{ab}}$ & 1.92 & 1660 & 1620 & 2.3 & 1.80 \\
\hline & 1200 & & 88.7 & 60 & 104 & $53.2^{\mathrm{ab}}$ & 1.96 & 1652 & 1634 & 2.8 & 2.13 \\
\hline & 4800 & & 88.3 & 59.2 & 103.1 & $52.2^{\mathrm{ab}}$ & 1.98 & 1641 & 1606 & 2.7 & 2.17 \\
\hline & 0 & \multirow{4}{*}{$0.77^{2}$} & 88.2 & 60.8 & 104.7 & $53.7^{a b}$ & 1.96 & 1664 & 1527 & 5.7 & 1.70 \\
\hline & 300 & & 86.2 & 60.8 & 104.6 & $52.4^{a b}$ & 2.01 & 1626 & 1582 & 2.5 & 2.00 \\
\hline & 1200 & & 89.6 & 59.8 & 103.6 & $53.4^{\mathrm{ab}}$ & 1.95 & 1653 & 1636 & 1.0 & 2.00 \\
\hline & 4800 & & 90.3 & 60.8 & 104.2 & $54.8^{a}$ & 1.90 & 1641 & 1614 & 2.1 & 1.58 \\
\hline & 0 & \multirow{4}{*}{$0.87^{3}$} & 84.1 & 60.9 & 104.9 & $51.2^{\mathrm{ab}}$ & 2.06 & 1662 & 1596 & 5.3 & 1.30 \\
\hline & 300 & & 90.1 & 60.2 & 103.9 & $54.1^{a b}$ & 1.92 & 1669 & 1628 & 2.7 & 1.94 \\
\hline & 1200 & & 90.2 & 60.3 & 105 & $54.3^{a b}$ & 1.94 & 1670 & 1653 & 0.2 & 2.29 \\
\hline & 4800 & & 88.3 & 58.9 & 103 & $52^{\mathrm{ab}}$ & 1.99 & 1670 & 1589 & 1.7 & 2.47 \\
\hline \multirow[t]{2}{*}{0.25} & 0 & \multirow[b]{2}{*}{ SEM } & 84.5 & 61.9 & 103.8 & $52.2^{\mathrm{ab}}$ & 2.01 & 1680 & 1571 & 6.9 & 1.34 \\
\hline & & & 0.83 & 0.51 & 0.34 & 0.53 & 0.02 & 13.3 & 15.3 & 0.55 & 0.14 \\
\hline \multicolumn{12}{|c|}{ Main effect means } \\
\hline \multirow{4}{*}{0.12} & 0 & & $86.1^{b}$ & 60.1 & 104 & $51.7^{b}$ & $2.02^{\mathrm{a}}$ & 1654 & $1551^{b}$ & $5.4^{\mathrm{a}}$ & $1.65^{a b}$ \\
\hline & 300 & & $87.8^{a b}$ & 61 & 103.9 & $53.4^{a}$ & $1.95^{b}$ & 1652 & $1610^{a}$ & $2.5^{b}$ & $1.91^{a b}$ \\
\hline & 1200 & & $89.4^{\mathrm{a}}$ & 60.1 & 104.2 & $53.6^{\mathrm{a}}$ & $1.95^{\mathrm{b}}$ & 1663 & $1641^{\mathrm{a}}$ & $1.3^{b}$ & $2.14^{\mathrm{a}}$ \\
\hline & 4800 & & $89^{a b}$ & 59.6 & 103.4 & $53^{a b}$ & $1.96^{\mathrm{b}}$ & 1651 & $1603^{a b}$ & $2.9^{b}$ & $2.07^{a b}$ \\
\hline 0.25 & 0 & & $86.2^{\mathrm{ab}}$ & 61.9 & 103.8 & $53.2^{\mathrm{ab}}$ & $1.96^{\mathrm{ab}}$ & 1678 & $1560^{\mathrm{ab}}$ & $6.9^{a}$ & $1.34^{b}$ \\
\hline \multirow{3}{*}{0.12} & & 0.67 & 87.5 & 60 & $103.2^{b}$ & 52.4 & 1.98 & 1657 & 1598 & 3.2 & 2.01 \\
\hline & & 0.77 & 88.6 & 60.5 & $104.3^{a}$ & 53.6 & 1.96 & 1665 & 1590 & 2.8 & 1.82 \\
\hline & & \multirow{4}{*}{0.87} & 88.2 & 60.1 & $104.2^{\mathrm{ab}}$ & 52.9 & 1.98 & 1672 & 1616 & 2.5 & 2.00 \\
\hline 0.25 & & & 86.2 & 61.9 & $103.8^{\mathrm{ab}}$ & 53.2 & 1.96 & 1678 & 1560 & 6.9 & 1.34 \\
\hline 0.12 & \multirow[t]{2}{*}{86.2} & & 88.1 & $60.2^{b}$ & 103.4 & 53 & 1.97 & 1655 & 1601 & $2.9^{b}$ & $1.94^{\mathrm{a}}$ \\
\hline 0.25 & & & $61.9^{\mathrm{a}}$ & 103.8 & 53.2 & 1.96 & 1678 & 1603 & $6.9^{\mathrm{a}}$ & $1.34^{b}$ & \\
\hline \multicolumn{12}{|c|}{ p-values (significance of effect) } \\
\hline & Phytase & & 0.019* Q & 0.282 & 0.425 & $0.044^{*} \mathrm{Q}$ & $0.045^{*}$ & 0.719 & $0.001^{* *} \mathrm{Q}$ & $<.0001^{* * *} \mathrm{Q}$ & $0.060^{\dagger} \mathrm{Q}$ \\
\hline & Lysine & & 0.533 & 0.604 & $0.012 * \mathrm{~L}$ & $0.176 \mathrm{~L}$ & 0.644 & 0.575 & 0.328 & 0.525 & 0.442 \\
\hline & Lysine*phytase & & 0.168 & 0.200 & 0.121 & $0.051^{*}$ & 0.106 & 0.913 & 0.570 & 0.741 & 0.111 \\
\hline & AvP & & 0.217 & 0.068 & 0.911 & 0.768 & 0.750 & 0.457 & 0.144 & $<.0001^{* * *}$ & $0.017^{*}$ \\
\hline
\end{tabular}

Statistically significant ${ }^{\dagger} p \leq 0.10,{ }^{*} p \leq 0.05,{ }^{* *} p \leq 0.01,{ }^{* * *} p \leq 0.001$. ${ }^{\text {a-b }}$ Show significant differences among treatment means.

${ }^{1}$ Analyzed values in order are: $0.69,0.67,0.68$, and 0.7 .

${ }^{2}$ Analyzed values in order are: $0.8,0.76,0.79$, and 0.78 .

${ }^{3}$ Analyzed values in order are: $0.86,0.87,0.89$, and 0.83 .

Dig. digestible; L, linear effect; $Q$, quadratic effect. 
sion of $1200 \mathrm{FTU} / \mathrm{kg}$ of a 6-phytase from A. oryzae produced a greater number of eggs laid in comparison to $800 \mathrm{FTU} / \mathrm{kg}$, and likewise $800 \mathrm{FTU} / \mathrm{kg}$ was better than $400 \mathrm{FTU} / \mathrm{kg}$ in Hy-Line W36 hens. In contrast, Silva et al. ${ }^{28}$ did not find differences between 300, 600, and $1200 \mathrm{FTU} / \mathrm{kg}$ of a 3-phytase from A. niger. Additionally, Silva et al. ${ }^{28}$ recommended using $300 \mathrm{FTU} / \mathrm{kg}$ phytase in order to improve FCR in Lohman Brown hens. The inconsistency in the response to different doses of phytase could be explained by differences due to the origin of the enzyme. Studies in vitro have found that phytases can differ considerably in intrinsic catalytic properties. $^{27,29}$ Onyango et al. 30 reported a higher residual activity of a 6- phytase from E. coli in vivo compared with a similar phytase from P. lycii when $1000 \mathrm{FTU} / \mathrm{kg}$ dose was evaluated in the digesta obtained from gizzard, jejunum, and ileum of seven day-old chicks.

In the present reseach, unlike egg production, egg weight remained unchanged when phytase was added or even when dLys content varied $F_{12,169}=1.44$, $p=0.15$, although both factors have been stated to positively influence egg weight. 29, 31 Only, egg weight was higher in hens fed the phytase-free diet containing $0.25 \%$ avP than the average of those fed diets with $0.12 \%$ avP $F_{12,169}=3.70$, $\mathrm{P}=0.06$, as also reported by Ceylan et al. ${ }^{32}$ and Englmaierová et al. ${ }^{33}$, but in contrast from studies by Augspurger et al, ${ }_{1}^{34}$ Lim et al., ${ }^{21}$ and Viana et al. ${ }^{35}$ (Table 3).

Despite no influence of phytase and dLys on egg weight, an interaction was evident in egg mass. Thus, at $0.77 \%$ dLys, phytase at 1200 and $4800 \mathrm{FTU} / \mathrm{kg}$ gave better production than $300 \mathrm{FTU} / \mathrm{kg}$. In contrast, in the others two levels of dLys $(0.67 \%$ and $0.87 \%), 4800 \mathrm{FTU} / \mathrm{kg}$ affected negatively egg mass $\mathrm{F}_{12,169}=1.86$, $p=0.04$. In spite of the interaction, the quadratic response to phytase doses, with a maximum at $1200 \mathrm{FTU} / \mathrm{kg}$ in egg production highlights the adverse response in production at $4800 \mathrm{FTU} / \mathrm{kg}$ in this trial $\mathrm{F}_{2,179}=2.56, \mathrm{p}=0.07$. Furthermore, incremental dLys levels resulted in positively linear responses in egg mass, highlighting the influential effect of dLys on production, where $0.87 \%$ dLys maximized egg mass $F_{1,180}=3.55, p=0.06$. Egg mass average from hens fed $0.12 \%$ avP diets was similar to the control diet $F_{12,169}=0.57, p=0.45$ (Table 3).

Feed consumption was lower in hens fed diets with $0.67 \%$ dLys compared with those fed $0.77 \%$; meanwhile, $0.87 \%$ was similar to 0.67 and $0.77 \%$ levels $F_{12,169}=1.85, p=0.04$. Additionally, a linear effect of feed intake was obtained to increasing dLys concentration, indicating an insufficient dietary supply with $0.67 \%$ $\mathrm{F}_{1,180}=4.79, \mathrm{p}=0.03$ (Table 3). Laying hens can adjust feed consumption to nutrient content of the diet, particularly energy, ${ }^{36}$ and to reduce intake of mineral deficient diets, ${ }^{37}$ although regarding lysine it is not clear. Torii et al. ${ }^{38}$ found that the restriction of L-lysine in the diet caused low feed consumption in rats, leading to anorexia and growth retardation, and it was remedied by blood lysine infusion. Torii's study showed that the ventromedial portion of the hypothalamus and the lateral hypothalamic area in the brain are responsible for the regulation of lysine levels in rats, demonstrated a role of central nervous system in lysine appetite. In the current study, low consumption of the $0.67 \%$ dLys diets probably resulted in low metabolic activity and reduced egg production, which was partially offset by phytase addition.

In the literature, there is no common recommendation for dLys level in the diet for white laying hen; the Bovans guide suggests $903 \mathrm{mg} / \mathrm{d}$ of consumption for optimal production, ${ }^{39} \mathrm{NRC}$ goes down to $580 \mathrm{mg} / \mathrm{d}$, or $690 \mathrm{mg} / \mathrm{d}$ when using 
$2900 \mathrm{kcal}$ in the diet. ${ }^{25}$ Rostagno et al. ${ }^{40}$ recommended intermediate values of $756 \mathrm{mg} / \mathrm{d}$ for 40 week-old hens and $708 \mathrm{mg} / \mathrm{d}$ for 65 week-old. Silva et al. ${ }^{14}$ estimated that dLys consumption of 707, 660, and $669 \mathrm{mg} / \mathrm{hen} / \mathrm{d}$ could optimize egg mass in Dekalb White hens of 37-40, 41-44, and 45-48 week-old, respectively. The levels recommended by Silva's study were close to the averages in this study of $692 \mathrm{mg} / \mathrm{d}$ in the lowest dLys diets tested and taken as deficient.

Despite that dLys influence was significant on feed consumption, phytase impact present in other parameters like egg production, remained in the FCR. Thus, phytase reduced FCR relative to no addition of the enzyme in diets with $0.12 \%$ avP $F_{12,169}=2.43, p=0.07$, contrasting with previous reports (Table 3 ). Augspurger et al. ${ }^{34}$ found that there was no change in FCR when 150, 300, and $10000 \mathrm{FTU} / \mathrm{kg}$ doses from a 6-phytase, produced by E. coli and expressed in A. niger, was evaluated in White Leghorn hens fed $0.10 \%$ avP. Silversides et al. ${ }^{31}$ reported similar results with 300, 500, and $700 \mathrm{FTU} / \mathrm{kg}$ doses of a 6-phytase from E. coli expressed in S. pombe in 34 to 40 week-old ISA-white hens. In this analysis, maximum feed consumption allowed by hen, could have resulted in the lack of an effect on egg weight. Phytase inclusion was able to increase nutrient availability, since, even with the same quantity of feed eaten, better productive performance was obtained for all doses tested (300, 1 200, and 4800 FTU/kg), improving FCR in those hens. Layers fed diets containing $0.25 \%$ avP gave an intermediate FCR $F_{12,169}=2.56, P=0.63$, and it is important to highlight that the extra-phosphoric effect was obtained even with standard doses, although the effectiveness of phytase was relating to dose rate.

At the beginning of the experiment the average BW was similar among hens $F_{12,169}=0.81, p>0.07$, but at the end of experimental period, highly statistical significances were found $F_{12,169}=2.24, p=0.01$. Layers fed low avP diets with 300 and $1200 \mathrm{FTU} / \mathrm{kg}$ phytase showed a higher final BW than those fed without phytase with the same avP level. Inclusion of $4800 \mathrm{FTU} / \mathrm{kg}$ phytase or increasing avP to $0.25 \%$ showed intermediate body weights at the end of the experimental period. Layers fed diets without phytase had more weight loss; those fed diets containing $0.12 \%$ avP lost $5.4 \%$, while the phytase-free $0.25 \%$ avP diet gave losses of $7.4 \%$. Hens fed phytase at 300, 1 200, and 4800 FTU/kg showed BW losses of 2.5, 1.3, and $2.2 \%$, respectively. Final BW and BW loss showed highly significant quadratic responses to increasing phytase dose, with the maximum at 1200 FTU/ $\mathrm{kg}, \mathrm{F} 2,179=17.79, \mathrm{p}<0.01$ (Table 3).

A reduction in the anti-nutritional effect of phytic acid from the diet by exogenous phytase addition was evident with all three doses evaluated, however, at $1200 \mathrm{FTU} / \mathrm{kg}$ the response was greater. A higher phytic acid hydrolysis by the highest phytase dose could have released more $\mathrm{P}_{1}^{41-43}$ and reduced the chelating capacity of intact phytic acid and high inositol esters. Thus, nutrients such as protein $^{44}$ and carbohydrates ${ }^{45}$ could have been more available, leading to an improvement in production and less use of body reserves by the layers. Silversides, et al. ${ }^{31}$ found that only $700 \mathrm{FTU} / \mathrm{kg}$ phytase gave positive changes in BW when 300, 500, and $700 \mathrm{FTU} / \mathrm{kg}$ doses were evaluated. Scott et al. ${ }^{46}$ demonstrated that inclusion of 250 and $500 \mathrm{FTU} / \mathrm{kg}$ of 3-phytase from A. niger prevented BW loss in a proportional manner, without being affected by changes in dietary $\mathrm{P}$ and $\mathrm{Ca}$ levels, demonstrating that phytase has the capacity to maintain egg production without use of body reserves. Nevertheless, contrary results have been published where 
any significant improvements in hen BW have been evident with incremental phytase doses. ${ }^{34,47}$ Francesch et al. ${ }^{19}$ observed greater BW gain with the use of 300 and $500 \mathrm{FTU} / \mathrm{kg}$ phytase than with increasing inorganic P level in the diet (1.1 vs $3.2 \mathrm{~g} / \mathrm{kg}$ of non-phytic P), although $150 \mathrm{FTU} / \mathrm{kg}$ addition did not provide the same effect. Furthermore, the majority of layers lost BW during the experimental period, as to reported by Keshavarz ${ }^{48}$ with the evaluation of vitamin D3, 25-OH-D3 and $300 \mathrm{FTU} / \mathrm{kg}$ of phytase.

Layers fed with $0.25 \%$ avP diets without phytase gave lower abdominal fat deposition relative to those fed with $0.12 \%$ avP supplemented with $1200 \mathrm{FTU} / \mathrm{kg}$, $F_{12,169}=2.52, P=0.05$. Layers fed diets containing $0.25 \%$ avP had lower abdominal fat content than those fed $0.12 \%$ avP diets $\mathrm{Fl}_{2,169}=5.85, \mathrm{P}=0.02$ (Table 3). Phytase addition seemed to influence the energy reserves in laying hens, and this could be related with the fact that high phytase doses may release inositol, which can affect the transport of lipoproteins into liver for the synthesis of triacylglycerol. ${ }^{49}$ Furthermore, higher phytase doses could also reduce the chelating capacity of phytic acid for lipids. ${ }^{50}$ The current trial highlights the fact that inorganic $\mathrm{P}$ supplementation was unable to promote better performance or maintain body reserves, while supplementation of $1200 \mathrm{FTU} / \mathrm{kg}$ phytase to a low avP diet improved performance and could serve as a tool to prolong laying period and help to improve profitability of egg production. This seems to be possible due to extra-phosphoric effect of the phytase and its greater effect when higher doses of enzyme were employed.

Layers fed $0.12 \%$ avP diets supplemented with either 1200 or $4800 \mathrm{FTU} / \mathrm{kg}$ phytase laid less broken eggs than those fed with no phytase supplementation. Nevertheless, there were no differences among those treatments and $0.12 \%$ avP diets with 0 or $300 \mathrm{FTU} / \mathrm{kg}$ phytase $\mathrm{F}_{3,169}=2.90, \mathrm{p}=0.04$. Similar results were obtained for soft-shell eggs, except that hens fed $4800 \mathrm{FTU} / \mathrm{kg}$ did not produce less defect eggs when fed the phytase-free $0.12 \%$ avP diet $F_{3,169}=2.91$, $p=0.04$. The responses in percent of broken $F_{2,179}=3.60, p=0.03$ and soft-eggs $F_{2,179}=3.58, P=0.03$ were fitted to quadratic models for phytase inclusions, with minimum value at $1200 \mathrm{FTU} / \mathrm{kg}$ dose. Also, increasing dLys levels in the diet resulted in a positive linear reduction for soft-shell eggs $F_{1,180}=3.55, p=0.06$. The production of dirty eggs was not influenced by treatments, and regression models were not significant $\mathrm{F}_{12,169}=1.09, \mathrm{p}=0.37$ (Table 4). Taking into consideration the results obtaining in egg classification, 1200 and $4800 \mathrm{FTU} / \mathrm{kg}$ of phytase improved eggshell formation, leading to a stronger structure, probably due to more mineral availability, decreasing the incidence of broken eggs. Hassanien and Sanaa ${ }^{51}$ found that $1000 \mathrm{FTU} / \mathrm{kg}$ phytase resulted in higher eggshell resistance to breakage in comparison to $700 \mathrm{FTU} / \mathrm{kg}$, which in turn showed increases relative to 500 or $0 \mathrm{FTU} / \mathrm{kg}$. In the same study, improved eggshell breaking results with phytase was reflected in higher $\mathrm{P}, \mathrm{Ca}$, and $\mathrm{Mg}$ levels in blood plasma. In the current study, $4800 \mathrm{FTU} / \mathrm{kg}$ was not as good as $1200 \mathrm{FTU} / \mathrm{kg}$ in reducing softshell egg incidence, nor were 300 or $0 \mathrm{FTU} / \mathrm{kg}$. This indicates that phytase dose effects on shell parameters can vary, which in turn can influence the production of marketable eggs.

Lysine is a structural component in the protein matrix of mammillary bodies in the eggshell 52 ; thus, it can alter mineral deposition during shell formation, leading to defects in the microstructure. ${ }^{53}$ In the present study, lysine influenced the 
Table 4. Effect of phytase and digestible lysine on egg marketing classification and egg quality test

in 40-65 week-old White Bovans laying hens

\begin{tabular}{|c|c|c|c|c|c|c|c|c|c|}
\hline \multirow{2}{*}{$\operatorname{AvP}(\%)$} & \multirow{2}{*}{ Phytase (FTU/kg) } & \multirow{2}{*}{ Dig. lysine (\%) } & \multicolumn{3}{|c|}{ Egg $(\%)$} & \multirow{2}{*}{$\begin{array}{c}\text { Marketable egg } \\
\text { mass }(\%)\end{array}$} & \multicolumn{3}{|c|}{ Egg quality test } \\
\hline & & & Broken & Soft-shell & Dirty & & Shell thickness (mm) & Haugh units & Pigmentation \\
\hline \multirow{12}{*}{0.12} & 0 & \multirow{4}{*}{0.67} & 0.59 & 0.63 & 0.7 & $42.5^{\mathrm{cd}}$ & 317 & 95.1 & 9.2 \\
\hline & \multirow{3}{*}{$\begin{array}{l}300 \\
1200 \\
4800\end{array}$} & & 0.43 & 0.67 & 0.45 & $46.3^{a b c}$ & 323 & 92.3 & 9.6 \\
\hline & & & 0.2 & 0.37 & 1.25 & $46.3^{a b c}$ & 316 & 91.1 & 9.5 \\
\hline & & & 0.25 & 0.94 & 1.07 & $45.1^{\mathrm{abcd}}$ & 314 & 91.7 & 9.4 \\
\hline & 0 & \multirow{4}{*}{0.77} & 0.58 & 1.13 & 0.62 & $46.5^{a b c}$ & 308 & 89.9 & 9.2 \\
\hline & 300 & & 0.61 & 1.02 & 1.26 & $43.9^{b c d}$ & 318 & 93.1 & 9.4 \\
\hline & 1200 & & 0.25 & 0.31 & 1.16 & $47.2^{a b}$ & 318 & 92.3 & 9.2 \\
\hline & 4800 & & 0.29 & 0.61 & 0.76 & $48.8^{\mathrm{a}}$ & 315 & 94.2 & 9.4 \\
\hline & 0 & \multirow{6}{*}{0.87} & 1.14 & 2.25 & 0.57 & $41.6^{d}$ & 310 & 89.6 & 9.2 \\
\hline & 300 & & 0.56 & 0.8 & 0.72 & $47.9^{a b}$ & 313 & 92.0 & 9.1 \\
\hline & 1200 & & 0.16 & 0.64 & 0.89 & $48.2^{\mathrm{a}}$ & 320 & 92.4 & 9.3 \\
\hline & 4800 & & 0.3 & 0.56 & 1.21 & $45.1^{\mathrm{abcd}}$ & 313 & 93.9 & 9.2 \\
\hline \multirow[t]{2}{*}{0.25} & 0 & & 0.39 & 1.55 & 1.39 & $43^{c d}$ & 314 & 89.3 & 9.2 \\
\hline & SEM & & 0.16 & 0.24 & 0.2 & 0.87 & 3.3 & 0.89 & 0.11 \\
\hline \multicolumn{10}{|c|}{ Main effect means } \\
\hline \multirow{8}{*}{0.25} & 0 & & $0.77^{\mathrm{a}}$ & $1.39^{\mathrm{a}}$ & 0.64 & $43.5^{\mathrm{a}}$ & 312 & 91.5 & 9.2 \\
\hline & 300 & & $0.55^{\mathrm{ab}}$ & $0.78^{a b}$ & 0.81 & $46^{\mathrm{ab}}$ & 318 & 92.5 & 9.4 \\
\hline & 1200 & & $0.2^{b}$ & $0.24^{b}$ & 1.05 & $47.2^{b}$ & 318 & 91.9 & 9.3 \\
\hline & 4800 & & $0.28^{b}$ & $0.43 a b$ & 1.01 & $46.3^{a b}$ & 314 & 93.3 & 9.33 \\
\hline & 0 & & $0.39^{a b}$ & $1.52^{a b}$ & 1.39 & $43^{a b}$ & 314 & 89.2 & 9.20 \\
\hline & & 0.67 & 0.37 & 0.65 & 0.83 & 45.1 & 318 & 92.6 & 9.43 \\
\hline & & 0.77 & 0.43 & 0.76 & 0.95 & 46.6 & 315 & 92.4 & 9.25 \\
\hline & & 0.87 & 0.54 & 1.06 & 0.85 & 45.7 & 314 & 92.1 & 9.21 \\
\hline 0.25 & & 0.87 & 0.39 & 1.52 & 1.39 & 43 & 314 & 89.2 & 9.20 \\
\hline 0.12 & \multirow{2}{*}{\multicolumn{2}{|c|}{0.39}} & 0.45 & 0.82 & 0.88 & $45.8^{b}$ & 316 & $92.4^{b}$ & 9.30 \\
\hline 0.25 & & & 1.52 & 1.39 & $43^{a}$ & 314 & $89.2^{\mathrm{a}}$ & 9.20 & \\
\hline \multicolumn{10}{|c|}{ p-values (significance of effect) } \\
\hline \multicolumn{3}{|c|}{ Phytase } & $0.037 * Q$ & $0.037 * Q$ & 0.392 & $0.017 * Q$ & 0.402 & 0.569 & 0.274 \\
\hline \multicolumn{3}{|c|}{ Lysine } & 0.656 & $0.335 \mathrm{~L}$ & 0.865 & 0.337 & 0.647 & $0.878 \mathrm{~L}$ & 0.226 \\
\hline \multirow{2}{*}{\multicolumn{3}{|c|}{$\begin{array}{c}\text { Lysine*phytase } \\
\text { AvP }\end{array}$}} & 0.873 & 0.381 & 0.646 & $0.056^{*}$ & 0.881 & 0.121 & 0.416 \\
\hline & & & 0.368 & 0.118 & 0.153 & $0.07^{\dagger}$ & 0.826 & $0.057^{*}$ & 0.629 \\
\hline
\end{tabular}

Statistically significant ${ }^{\dagger} p \leq 0.10,{ }^{* *} p \leq 0.05,{ }^{* *} p \leq 0.01,{ }^{* * *} p \leq 0.001$. ${ }^{a-d}$ Show significant differences among treatment means.

Dig. digestible; $L$, linear effect; $Q$, quadratic effect. 
incidence of soft-shell eggs, but not shell thickness, reinforcing the idea that microstructure conformation of eggshell has a greater influence than macro-structural components. This is because size and orientation of mineral crystals in the eggshell can directly affect mechanical properties. ${ }^{54}$ An important point to highlight on the design of the present study is the fact that individual caging system allowed the observation of dietary effects on egg cracking, avoiding those resulting from the limitation of cage space.

When non-sellable egg (broken and soft-shell) was subtracted from egg mass to give "marketable egg mass", dLys levels influence on the effect of phytase became more apparent $F_{12,169}=2.41, p=0.02$ (Table 4). Thus, in the current study, lysine shortage $(0.67 \%)$ decreased the use of nutrients released from phytase, resulting in a lower response to higher phytase doses. Additionally, for $0.87 \%$ dietary lysine without phytase, P shortage and high lysine content led to a nutritional imbalance that negatively impacted performance; better performance was achieved by phytase addition at 300 and $1200 \mathrm{FTU} / \mathrm{kg}$, but not at $4800 \mathrm{FTU} / \mathrm{kg}$. In medium level of dLys (0.77 \%), $300 \mathrm{FTU} / \mathrm{kg}$ was not able to get egg mass production to the level seen at 1200 and $4800 \mathrm{FTU} / \mathrm{kg}$ (Figure A). Only one previous study in poultry has been published on the combined implication of phytase dose and lysine level in diet. Selle et al. 46 in 7-28 day-old broilers, found that the addition of $500 \mathrm{FTU} / \mathrm{kg}$ 3-phytase from $A$. niger performed better with the dLys level considered as deficient $(10 \mathrm{~g} / \mathrm{kg})$ compare to the adequate level $(11.8 \mathrm{~g} / \mathrm{kg})$. Although, marketable egg mass was strongly affected in a quadratic manner by increasing of phytase dose, with a positive effect up to $1200 \mathrm{FTU} / \mathrm{kg} \mathrm{F}_{2,179}=5.61, \mathrm{p}=0.01$. Dietary $0.25 \%$ avP resulted in less marketable egg mass in comparison to $0.12 \%$ avP diets $F_{12,169}=7.24, P=0.01$. There was no effect of treatment on shell thickness $F_{12,169}=0.53, p=0.89$ and yolk pigment $F_{12,169}=1.10, p=0.36$. Layers fed $0.12 \%$ avP diets gave higher average Haugh units than diets with $0.25 \%$ avP $\mathrm{F}_{12,169}=3.72, \mathrm{p}=0.05$ (Table 4).

Bone breaking strength $F_{3,169}=4.29, p<0.01$ and ash weight $F_{3,169}=3.62$, $p=0.01$ was higher in tibia of hens fed diets with $1200 \mathrm{FTU} / \mathrm{kg}$ phytase relative to those fed without phytase. Bone breaking strength, representing bone status, is greater when P assimilation from diet is higher. ${ }^{49}$ In this context, $1200 \mathrm{FTU} / \mathrm{kg}$ phytase improved P bioavailability and in this way bone strength, relative to 300 and $4800 \mathrm{FTU} / \mathrm{kg}$, giving a quadratic effect. The same pattern was seen with ash weight is accord with the correlations mentioned by Kim et al, ${ }^{55}$ indicating that more $\mathrm{P}$ is released from diet with higher than standard doses of phytase to support bone status in laying hen. Adeola and Walk ${ }^{56}$ demonstrated that $\mathrm{P}$ utilization for bone mineralization from phytase release could be around 87.4 and $92.8 \%$ with 5 or $6 \mathrm{~g} / \mathrm{kg}$ of highly soluble $\mathrm{Ca}$, respectively. On other hand, addition of inorganic $P$ to diets resulted in similar bone breaking strength $F_{1,169}=0.92, P=0.34$ and ash weight $F_{1,169}=1.01, p=0.31$ as inclusions of 300 and $4800 \mathrm{FTU} / \mathrm{kg}$ phytase (Table 5). These bone status results suggest that an extra-phosphoric effect is obtained using $1200 \mathrm{FTU} / \mathrm{kg}$ in laying hens. Additionally, a dLys level and phytase dose interaction was seen in fat-free dry bone weight and ash weight $F_{12,169}=1.79$, $\mathrm{p}=0.01$ (Table 5) (Figure B). Additionally, changes in bone ash concentration can depend on dLys level in diet, which could be associated with the protein component of bone tissue, or the overall metabolic modification by dLys level of feed intake and laying rate. With 0.67 and $0.77 \%$ dLys, bone ash concentration was 

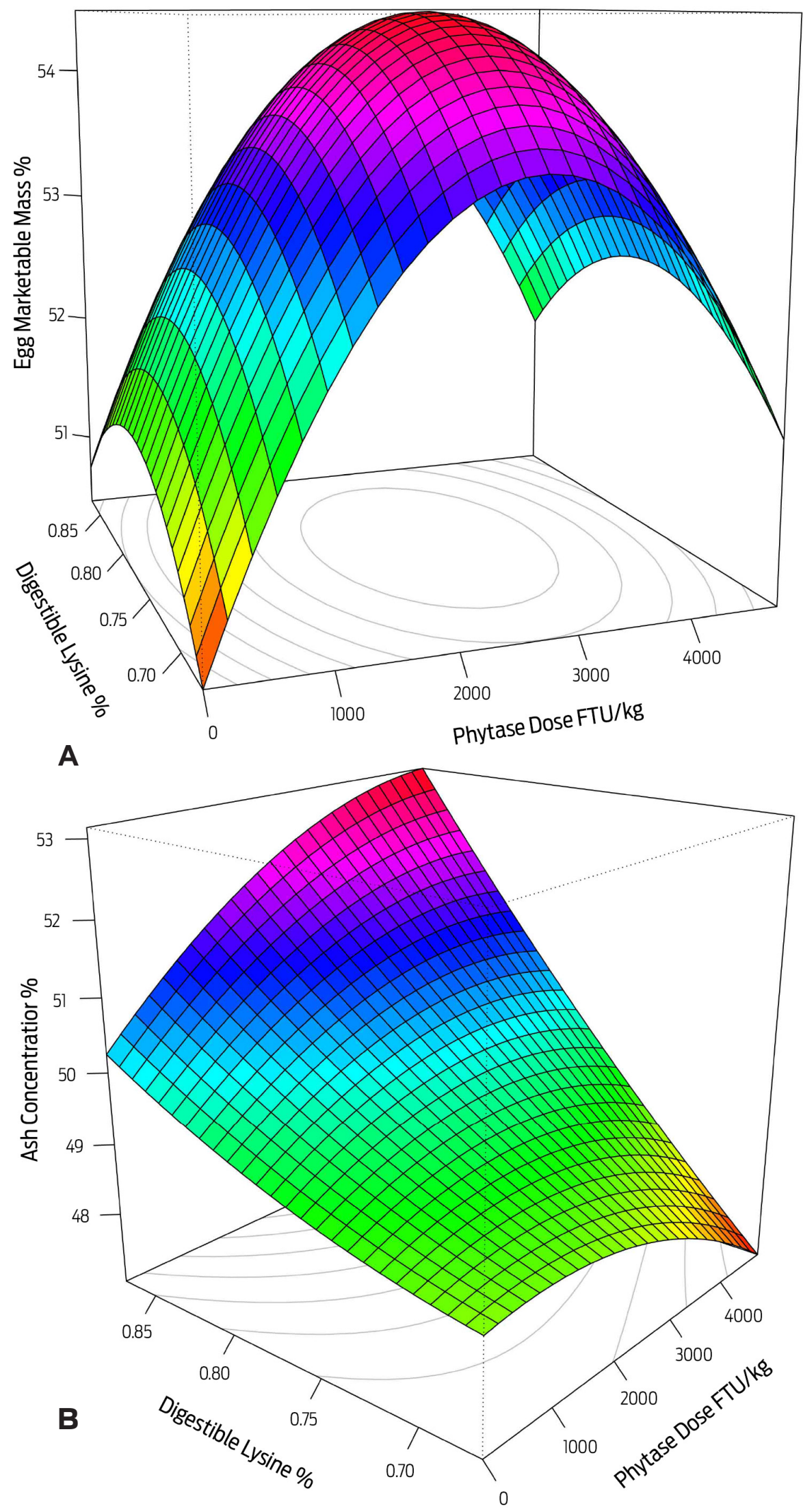

Figure 1. Response of egg marketable mass (A) and ash concentration in bone (B) to incremental digestible lysine and phytase dosing. 
Table 5. Effects of phytase and digestible lysine on bone parameters

of 65 week-old White Bovans laying hens

\begin{tabular}{|c|c|c|c|c|c|c|}
\hline $\operatorname{AvP}(\%)$ & $\begin{array}{l}\text { Phytase } \\
\text { (FTU/kg) }\end{array}$ & Dig. lysine (\%) & $\begin{array}{l}\text { Breaking strength } \\
\left(\mathrm{kg} / \mathrm{cm}^{2}\right)\end{array}$ & $\begin{array}{l}\text { Fat free-DM } \\
\text { weight (g) }\end{array}$ & $\begin{array}{c}\text { Ash concentration } \\
(\%)\end{array}$ & $\begin{array}{l}\text { Ash weight } \\
\text { (g) }\end{array}$ \\
\hline \multirow{13}{*}{0.12} & 0 & \multirow{4}{*}{0.67} & 16.1 & $4.26^{\mathrm{b}}$ & $48.2^{b c}$ & 2.05 \\
\hline & 300 & & 17.4 & $4.49^{a b}$ & $49.3^{b c}$ & 2.21 \\
\hline & 1200 & & 18.9 & $5.11^{\mathrm{a}}$ & $47.3^{C}$ & 2.42 \\
\hline & 4800 & & 18.3 & $4.61^{a b}$ & $48^{b c}$ & 2.2 \\
\hline & 0 & \multirow{4}{*}{0.77} & 16 & $4.01^{b}$ & $49.6^{b c}$ & 1.98 \\
\hline & 300 & & 18.6 & $4.43^{a b}$ & $51^{a b}$ & 2.26 \\
\hline & 1200 & & 19 & $4.78^{a b}$ & $48.8^{b c}$ & 2.33 \\
\hline & 4800 & & 16.7 & $4.49^{a b}$ & $48.6^{b c}$ & 2.18 \\
\hline & & & & & & \\
\hline & 0 & \multirow{5}{*}{0.87} & 17.3 & $4.41^{a b}$ & $50.1^{a b c}$ & 2.21 \\
\hline & 300 & & 17.8 & $4.78^{a b}$ & $48.3^{b c}$ & 2.3 \\
\hline & 1200 & & 18.2 & $3.99^{b}$ & $53.7^{\mathrm{a}}$ & 2.14 \\
\hline & 4800 & & 18.7 & $4.04^{b}$ & $53.4^{\mathrm{a}}$ & 2.16 \\
\hline \multirow[t]{2}{*}{0.25} & 0 & & 18.5 & $4.64^{\mathrm{ab}}$ & $49.4^{b c}$ & 2.29 \\
\hline & \multicolumn{2}{|c|}{ SEM } & 0.46 & 0.1 & 0.46 & 0.051 \\
\hline \multicolumn{7}{|c|}{ Main effect means } \\
\hline \multirow{4}{*}{0.12} & 0 & & $16.5^{\mathrm{b}}$ & $4.23^{b}$ & 49.3 & $2.08^{b}$ \\
\hline & 300 & & $17.9^{a b}$ & $4.56^{\mathrm{ab}}$ & 49.5 & $2.26^{\mathrm{ab}}$ \\
\hline & 1200 & & $18.7^{\mathrm{a}}$ & $4.63^{a}$ & 49.9 & $2.3^{a}$ \\
\hline & 4800 & & $17.9^{a b}$ & $4.38^{a b}$ & 50 & $2.18^{a b}$ \\
\hline 0.25 & 0 & & $18.5^{a b}$ & $4.64^{a b}$ & 49.4 & $2.29^{a b}$ \\
\hline \multirow{3}{*}{0.12} & & 0.67 & 17.6 & $4.62^{\mathrm{a}}$ & $48.2^{b}$ & 2.22 \\
\hline & & 0.77 & 17.6 & $4.43^{a b}$ & $49.1^{b}$ & 2.19 \\
\hline & & \multirow{2}{*}{0.87} & 18 & $4.31^{b}$ & $51.3^{a}$ & 2.2 \\
\hline 0.25 & & & 18.5 & $4.64^{\mathrm{ab}}$ & $49.4^{a b}$ & 2.29 \\
\hline 0.12 & \multirow{2}{*}{\multicolumn{2}{|c|}{18.5}} & 17.7 & 4.47 & 49.6 & 2.21 \\
\hline 0.25 & & & 4.64 & 49.4 & 2.29 & \\
\hline \multicolumn{7}{|c|}{ p-values (significance of effect) } \\
\hline \multicolumn{3}{|c|}{ Phytase } & $0.006^{* *} \mathrm{Q}$ & $0.019 * \mathrm{~L}$ & 0.649 Q & $0.015^{*} \mathrm{Q}$ \\
\hline \multicolumn{3}{|c|}{ Lysine } & 0.722 & $0.035^{*} \mathrm{~L}$ & $<.0001^{* * *}$ & 0.847 \\
\hline \multicolumn{3}{|c|}{ Lysine*phytase } & 0.354 & $<.0001^{* * *}$ & $<.0001^{* * *}$ & 0.148 \\
\hline \multicolumn{3}{|c|}{ AvP } & 0.34 & 0.28 & 0.687 & 0.315 \\
\hline
\end{tabular}

Statistically significant ${ }^{*} p \leq 0.05,{ }^{* *} p \leq 0.01,{ }^{* * *} p \leq 0.001$. ${ }^{a-c}$ Show significant differences among treatment means.

Dig. digestible; L, linear effect; $Q$, quadratic effect. 
reduced with increasing phytase dose, but at $0.87 \%$ dLys, the response was the opposite. Contrary to this result, Ravindran et al. ${ }^{57}$ did not observe changes in toe ash content with incremental levels of lysine in 28 week-old broilers.

It was possible that inclusion of $4800 \mathrm{FTU} / \mathrm{kg}$ phytase would have increased the hydrolysis of phytic acid, and therefore released more nutrients from the diet. Nevertheless, this dose suppressed performance and gave no beneficial effects on bone parameters in hens fed 0.67 and $0.87 \%$ dLys levels, compare to 1200 FTU/ $\mathrm{kg}$ phytase. This could be a consequence of unbalanced ratio of nutrients, specially Ca:P, taking into account the constant supply of $\mathrm{Ca}$ across treatments. Li et al.58 reported in chickens that while dietary avP level increased, total and ionized $\mathrm{Ca}$ in plasma decreased, concluding that excess or deficiency of either mineral can interfere directly in the homeostasis of the other and negatively affect animal performance and bone development. Few studies have tested high inclusion of phytase in laying hen, and, contrary to the current study, Meyer and Parsons ${ }^{59}$ did not find changes in productive responses when using 150, 250, and $15000 \mathrm{FTU} / \mathrm{kg}$ of a 6-phytase from E. coli in W-36 Hy-Line layers. Similar results were reported by Augspurger et al. ${ }^{34}$ with 250, 500, 1000, and $10000 \mathrm{FTU} / \mathrm{kg}$ from a 6-phytase from E.coli in Single-Comb White Leghorn. In this study, $4800 \mathrm{FTU} / \mathrm{kg}$ phytase increased egg production only in $0.77 \%$ dLys diets.

\section{Conclusion}

Supplementation with $1200 \mathrm{FTU} / \mathrm{kg}$ of an E.coli derived phytase improved productive performance of laying hens, while maintained body reserves and bone tissue. Similar effects were not observed with 300 or $4800 \mathrm{FTU} / \mathrm{kg}$ of this phytase, or inorganic $P$ supplementation. It seems that phytase supplementation influenced nutrients other than just $P$, and that higher phytase doses improved the utilization of phosphorus and other nutrients. Furthermore, dietary levels of dLys influenced phytase efficiency, interfering in the response obtained in productive performance and body composition status in laying hens, without equivalence of phytase addition for dLys level in diet. 


\section{Funding}

The authors express their gratitude to the DGAPA and PAPIIT project IN 214015 for financial support.

\section{Conflicts of interest}

The authors certify that they no have conflict of interest.

\section{Author contributions}

IMR, CLC, EAG, JAM, and GG designed the study. IMR performed the experiment and analyzed the data. IMR and CLC prepared the manuscript. All authors read and approved the final manuscript.

\section{References}

1. Selle P, Ravindran V. Microbial phytase in poultry nutrition. Anim Feed Sc Tech. 2007;135:1-41. doi: 10.1016/j.anifeedsci.2006.06.010.

2. Doria E, Galleschi L, Calucci L, Pinzino C, Pilu R, Cassani E, et al. Phytic acid prevents oxidative stress in seeds: evidence from a maize (Zea mays L.) low phytic acid mutant. Journal of Experimental Botany. 2009;60(3):967-78. doi: 10.1093/jxb/ern345.

3. Angel R, Tamim NM, Applegate TJ, Dhandu AS, Ellestad LE. Phytic acid chemistry: influence on phytin-phosphorus availability and phytase efficacy1. J App Poult Res. 2002;11(4):471-80. doi: 10.1093/japr/11.4.471.

4. Rutherfurd SM, Edwards AC, Selle PH. Effect of phytase on lysine-rice pollard complexes. Manipulating pig production vi. Aus Pig Sci Assoc. 1997:248.

5. Truong HH, Yu S, Peron A, Cadogan DJ, Khoddami A, Roberts TH, et al. Phytase supplementation of maize-, sorghum- and wheat-based broiler diets with identified starch pasting properties influences phytate (IP6) and sodium jejunal and ileal digestibility. Animal Feed Science and Technology. 2014;198:248-56. doi: https://doi.org/10.1016/j.anifeedsci.2014.10.007.

6. Nahm KH. Efficient phosphorus utilization in poultry feeding to lessen the environmental impact of excreta. World's Poultry Science Journal. 2007;63(4):62554. doi: 10.1017/S0043933907001663.

7. Cowieson AJ, Wilcock P, Bedford MR. Super-dosing effects of phytase in poultry and other monogastrics. World's Poultry Science Journal. 2011;67(2):225-36. doi: 10.1017/S0043933911000250.

8. Dersjant-Li Y, Awati A, Schulze H, Partridge G. Phytase in non-ruminant animal nutrition: a critical review on phytase activities in the gastrointestinal tract and influencing factors. Journal of the Science of Food and Agriculture. 2015;95(5):878-96. doi: 10.1002/jsfa.6998.

9. Cheryan M, Rackis JJ. Phytic acid interactions in food systems. C R C Critical Reviews in Food Science and Nutrition. 1980;13(4):297-335. doi: 10.1080/10408398009527293.

10. Selle PH, Cowieson AJ, Cowieson NP, Ravindran V. Protein-phytate interactions in pig and poultry nutrition: a reappraisal. NutritionResearch Reviews. 2012;25(1):1-17. doi: 10.1017/s0954422411000151.

11. Bye JW, Cowieson NP, Cowieson AJ, Selle PH, Falconer RJ. Dual effects of sodium phytate on the structural stability and solubility of proteins. Journal of Agricultural and Food Chemistry. 2013;61(2):290-5. doi: 10.1021/jf303926v. 
12. Boisen $\mathrm{S}$, Hvelplund $\mathrm{T}$, Weisbjerg MR. Ideal amino acid profiles as a basis for feed protein evaluation. Livestock Production Science. 2000;64(2):239-51. doi: 10.1016/S0301-6226(99)00146-3.

13. Coon CN. Feeding commercial egg-type layers. In: Bell DD, Weaver WD, editors. Commercial chicken meat and egg production. Boston (MA): Springer US, 2002. p. 287-328.

14. Silva EP, Malheiros EB, Sakomura NK, Venturini KS, Hauschild L, Dorigam JCP, et al. Lysine requirements of laying hens. Livestock Science. 2015;173:69-77. doi: 10.1016/j.livsci.2015.01.005.

15. Bedford M, Walk C. Reduction of phytate to tetrakisphosphate (IP4) to triphosphate (IP3), or perhaps even lower, does not remove its antinutritive properties. In: Walk C, Kuhn I, Kidd S, editors. Phytate destruction consequences for precision animal nutrition. The Netherlands (NL): Wageningen Academic, 2016. p. 45-51.

16. Zeller E, Schollenberger M, Kuhn I, Rodehutscord M. Dietary effects on inositol phosphate breakdown in the crop of broilers. Archives of animal nutrition. 2016;70(1):57-71. doi: 10.1080/1745039x.2015.1112622.

17. Wilcock $\mathrm{P}$, Walk CL. Low phytate nutriion - what is the pig and poultry industry doing to counter dietary phytate as an anti-nutrient and how is it being applied? In: Walk CL, Kuhn I, Stein HH, Kidd MT, Rodehutscord M, editors. Phytate destruction consequencres for precision animal nutrition. The Netherlands (NL): Wageningen Academic, 2016. p. 86-106.

18. Selle PH, Ravindran V, Cowieson AJ, Bedford MR. Phytate and phytase. In: Bedford MR, Partridge GG, editors. Enzymes in farm animal nutrition. 2nd ed. Wallingford (UK): Centre for Agriculture and Biosciences International, 2010. p. $160-205$.

19. Francesch M, Broz J, Brufau J. Effects of an experimental phytase on performance, egg quality, tibia ash content and phosphorus bioavailability in laying hens fed on maize- or barley-based diets. British Poultry Science. 2005;46(3):340-8. doi: 10.1080/00071660500127001.

20. Keshavarz K. The effect of different levels of nonphytate phosphorus with and without phytase on the performance of four strains of laying hens. Poultry Science. 2003;82(1):71-91. doi: 10.1093/ps/82.1.71.

21. Lim HS, Namkung H, Paik IK. Effects of phytase supplementation on the performance, egg quality, and phosphorous excretion of laying hens fed different levels of dietary calcium and nonphytate phosphorous. Poultry Science. 2003;82(1):92-9. doi: 10.1093/ps/82.1.92.

22. Mellef J, Dridi A, Agrebi A, Belhaj O. Effets de l'ajout de phytase dans la ration alimentaire sur les performances de ponte des poules pondeuses. R Med Vet. $2011 ; 162(6): 304$.

23. Agbede JO, Adebayo IA, Osho IB, Bankole OM. Influence of microbial phytase on amino acid digestibility of caecectomised laying hens fed marginally low methionine-based diet. Adv Anim Biosci. 2010;1(2):453-4. doi: 10.1017/ S2040470010000750.

24. Selle PH, Ravindran V, Ravindran G, Bryden WL. Effects of dietary lysine and microbial phytase on growth performance and nutrient utilisation of broiler chickens. J Anim Sci. 2007;20(7):1100-7. doi: 10.5713/ajas.2007.1100. 
25. National Research Council. Nutrient requirements of poultry. 9th ed. Washington, DC: The National Academies Press, 1994. p. 176.

26. Horwitz W, Latimer GW, Association of Official Analytical Chemists I. Official methods of analysis of AOAC international. Gaithersburg, Maryland: AOAC International, 2006.

27. Weaver JD, Ullah AHJ, Sethumadhavan K, Mullaney EJ, Lei XG. Impact of assay conditions on activity estimate and kinetics comparison of Aspergillus niger phyA and Escherichia coli appA2 phytases. Journal of Agricultural and Food Chemistry. 2009;57(12):5315-20. doi: 10.1021/jf900261n.

28. Silva JHVd, Araujo JAd, Goulart CdC, Costa FGP, Sakomura NK, Furtado DA. Influência da interação fósforo disponível $\times$ fitase da dieta sobre o desempenho, os níveis plasmáticos de fósforo e os parâmetros ósseos de poedeiras comerciais. $\mathrm{R}$ Bras Zootec. 2008;37:2157-65. doi: 10.1590/S1516-35982008001200012.

29. Novak C, Yakout $H$, Scheideler $S$. The combined effects of dietary lysine and total sulfur amino acid level on egg production parameters and egg components in Dekalb Delta laying hens 1. Poultry Science. 2004;83(6):977-84. doi: 10.1093/ps/83.6.977.

30. Onyango EM, Bedford MR, Adeola O. Phytase activity along the digestive tract of the broiler chick: a comparative study of an Escherichia coli-derived and Peniophora lycii phytase. Canadian Journal of Animal Science. 2005;85(1):61-8. doi: 10.4141/A04-067.

31. Silversides FG, Scott TA, Korver DR, Afsharmanesh M, Hruby M. A Study on the interaction of xylanase and phytase enzymes in wheat-based diets fed to commercial white and brown egg laying hens 1. Poultry Science. 2006;85(2):297305. doi: 10.1093/ps/85.2.297.

32. Ceylan N, Scheideler SE, Stilborn HL. High available phosphorus corn and phytase in layer diets. Poultry Science. 2003;82(5):789-95. doi: 10.1093/ ps/82.5.789.

33. Englmaierová M, Dlouhá G, Marounek M, Skřivan M. Efficacy of contrast levels of non-phytate phosphorus and Aspergillus niger phytase in hens fed wheatmaize-based diets. Czech Journal of Animal Scienc. 2012; 11:499-505. doi: 10.17221/6382-CJAS.

34. Augspurger NR, Webel DM, Baker DH. An Escherichia coli phytase expressed in yeast effectively replaces inorganic phosphorus for finishing pigs and laying hens. Asian Journal of Animal Science. 2007;85(5):1192-8. doi: 10.2527/ jas.2006-340.

35. Viana MTdS, Albino LFT, Rostagno HS, Barreto SLdT, Silva EAd, Florentino WM. Efeito da suplementação de enzima fitase sobre o metabolismo de nutrientes e o desempenho de poedeiras. Revista Brasileira de Zootecnia. 2009;38:107480. doi: 10.1590/S1516-35982009000600015.

36. Scanes CG, Campbell R, Griminger P. Control of energy balance during egg production in the laying hen. The Journal of Nutrition. 1987;117(3):605-11. doi: 10.1093/jn/117.3.605.

37. Barkley GR, Miller HM, Forbes JM. The ability of laying hens to regulate phosphorus intake when offered two feeds containing different levels of phosphorus. British Journal of Nutrition. 2004;92(2):233-40. doi: 10.1079/BJN20041182.

38. Torii K, Yokawa T, Tabuchi E, Hawkins RL, Mori M, Kondoh T, et al. Recognition of deficient nutrient intake in the brain of rat with L-lysine deficiency monitored by 
functional magnetic resonance imaging, electrophysiologically and behaviorally. Amino Acids. 1996;10(1):73-81. doi: 10.1007/bf00806094.

39. Hendrix Genetics Company. Bovans nutrition management guide. The Netherlands-EU. 2009. https: //www.bovans.com/en/product/bovans-white/.

40. Rostagno H, Albino L, Donzele J, Gomes P, Oliveira R, Lopes D, et al. Tabelas brasileiras para aves e suínos. Composição de alimentos e exigências nutricionais. Viçosa, MG (BR): Universidade Federal de Viçosa, 2017.

41. Shirley RB, Edwards JHM. Graded levels of phytase past industry standards improves broiler performance. Poultry Science. 2003;82(4):671-80. doi: 10.1093/ps/82.4.671.

42. Van der Klis JD, Versteegh HA, Simons PC, Kies AK. The efficacy of phytase in corn-soybean meal-based diets for laying hens. Poultry Science. 1997;76(11):1535-42. doi: 10.1093/ps/76.11.1535.

43. Zeller E, Schollenberger M, Witzig M, Shastak Y, Kühn I, Hoelzle LE, et al. Interactions between supplemented mineral phosphorus and phytase on phytate hydrolysis and inositol phosphates in the small intestine of broilers 1, 2. Poultry Science. 2015;94(5):1018-29. doi: 10.3382/ps/pev087.

44. Prattley CA, Stanley DW, Voort FR. Protein-phytate interactions in soybeans. ॥ mechanism of protein-phytate binding as affected by calcium. J Food Biochem. 1982;6(4):255-72. doi: doi:10.1111/j.1745-4514.1982.tb00306.x.

45. Thompson LU, Yoon JH. Starch digestibility as affected by polyphenols and phytic acid. J Food Sci. 1984;49(4):1228-9. doi: 10.1111/j.1365-2621.1984. tb 10443.x.

46. Scott TA, Kampen R, Silversides FG. The effect of phosphorus, phytase enzyme, and calcium on the performance of layers fed wheat-based diets. Canadian Journal of Animal Science. 2000;80(1):183-90. doi: 10.4141/A99-082.

47. Yildiz $\mathrm{AO}$, Olgun $\mathrm{O}$, Cufadar $\mathrm{Y}$. The effect of manganese and phytase in the diet for laying hens on performance traits and eggshell quality. J Anim Vet Adv. 2010;9:32-6. doi: 10.3923/javaa.2010.32.36.

48. Keshavarz K. A comparison between cholecalciferol and 25-OH-cholecalciferol on performance and eggshell quality of hens fed different levels of calcium and phosphorus. Poultry Science. 2003;82(9):1415-22. doi: 10.1093/ ps/82.9.1415.

49. Burton LE, Wells WW. Myo-inositol deficiency: studies on the mechanism of lactation-dependent fatty liver formation in the rat. The Journal of Nutrition. 1979;109(8):1483-91. doi: 10.1093/jn/109.8.1483.

50. Cosgrove DJ. The chemistry and biochemistry of inositol polyphosphates. Rev Pure Appli Chem. 1966;16:209-24.

51. Hassanien HHM, Sanaa HME. Comparison difference levels of phytase enzyme supplementation on laying hen performance, egg quality and some blood parameters. Asian Journal of Poultry Science. 2011;5:77-85. doi: 10.3923/ ajpsaj.2011.77.85.

52. Hincke MT, Nys Y, Gautron J, Mann K, Rodriguez-Navarro AB, McKee MD. The eggshell: structure, composition and mineralization. Frontiers in bioscience (Landmark edition). 2012;17:1266-80.

53. Solomon SE. The eggshell: strength, structure and function. British Poultry Science. 2010;51(sup 1):52-9. doi: 10.1080/00071668.2010.497296. 
54. Hernández-Hernández A, Vidal ML, Gómez-Morales J, Rodríguez-Navarro AB, Labas $\mathrm{V}$, Gautron J, et al. Influence of eggshell matrix proteins on the precipitation of calcium carbonate (CaCO3). Journal of Crystal Growth. 2008;310(7):17549. doi: https://doi.org/10.1016/j.jcrysgro.2007.11.170.

55. Kim WK, Donalson LM, Herrera P, Woodward CL, Kubena LF, Nisbet DJ, et al. Research note: Effects of different bone preparation methods (fresh, dry, and fat-free dry) on bone parameters and the correlations between bone breaking strength and the other bone parameters. Poultry Science. 2004;83(10):16636. doi: 10.1093/ps/83.10.1663.

56. Adeola O, Walk CL. Linking ileal digestible phosphorus and bone mineralization in broiler chickens fed diets supplemented with phytase and highly soluble calcium. Poultry Science. 2013;92(8):2109-17. doi: 10.3382/ps.2013-03068.

57. Ravindran V, Selle PH, Ravindran G, Morel PCH, Kies AK, Bryden WL. Microbial phytase improves performance, apparent metabolizable energy, and ileal amino acid digestibility of broilers fed a lysine-deficient diet. Poultry Science. 2001;80(3):338-44. doi: 10.1093/ps/80.3.338.

58. Li W, Angel R, Kim SW, Jiménez-Moreno E, Proszkowiec-Weglarz M, Plumstead PW. Age and adaptation to Ca and P deficiencies: 2. Impacts on amino acid digestibility and phytase efficacy in broilers. Poultry Science. 2015;94(12):291731. doi: 10.3382/ps/pev273.

59. Meyer E, Parsons C. The efficacy of a phytase enzyme fed to Hy-Line W-36 laying hens from 32 to 62 weeks of age. The Journal of Applied Poultry Research. 2011;20(2):136-42. doi: 10.3382/japr.2010-00212. 